PREPARED FOR THE U.S. DEPARTMENT OF ENERGY, UNDER CONTRACT DE-AC02-76CH03073

PPPL-3673

PPPL-3673

UC-70

Fusion Implementation

by

J.A. Schmidt

February 2002

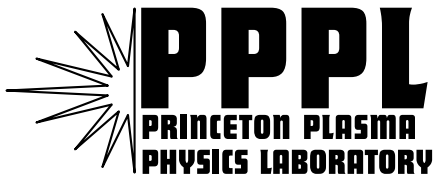

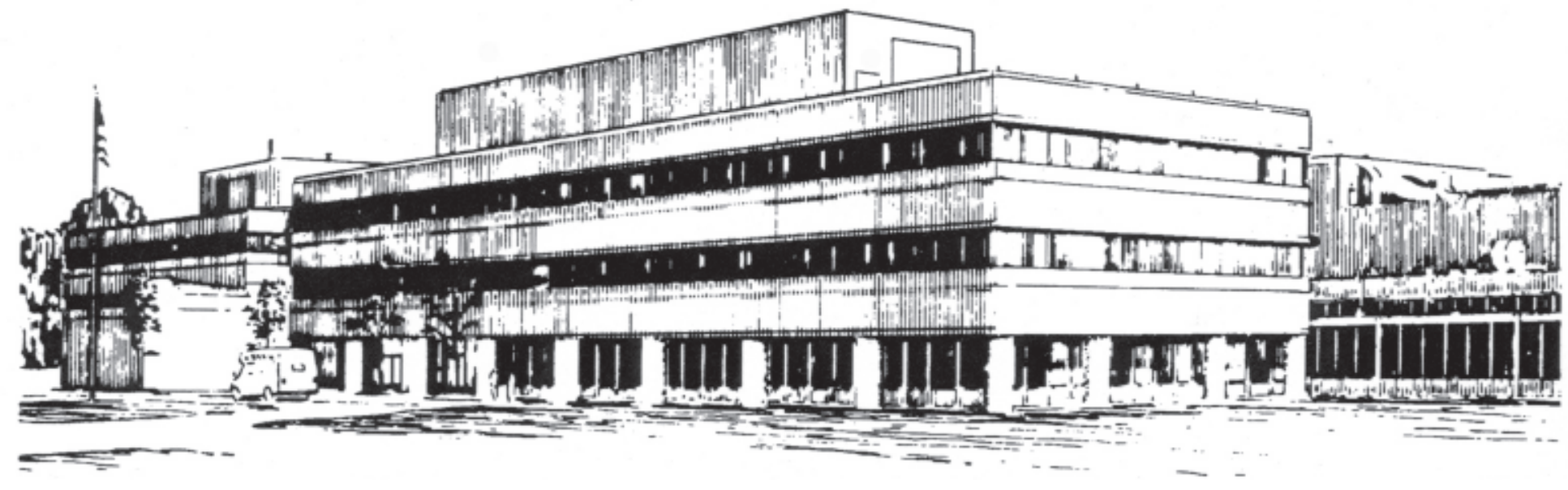

PRINCETON PLASMA PHYSICS LABORATORY PRINCETON UNIVERSITY, PRINCETON, NEW JERSEY 


\section{PPPL Reports Disclaimer}

This report was prepared as an account of work sponsored by an agency of the United States Government. Neither the United States Government nor any agency thereof, nor any of their employees, makes any warranty, express or implied, or assumes any legal liability or responsibility for the accuracy, completeness, or usefulness of any information, apparatus, product, or process disclosed, or represents that its use would not infringe privately owned rights. Reference herein to any specific commercial product, process, or service by trade name, trademark, manufacturer, or otherwise, does not necessarily constitute or imply its endorsement, recommendation, or favoring by the United States Government or any agency thereof. The views and opinions of authors expressed herein do not necessarily state or reflect those of the United States Government or any agency thereof.

\section{Availability}

This report is posted on the U.S. Department of Energy's Princeton Plasma Physics Laboratory Publications and Reports web site in Fiscal Year 2002. The home page for PPPL Reports and Publications is: http://www.pppl.gov/pub_report/

DOE and DOE Contractors can obtain copies of this report from:

U.S. Department of Energy

Office of Scientific and Technical Information

DOE Technical Information Services (DTIS)

P.O. Box 62

Oak Ridge, TN 37831

Telephone: (865) 576-8401

Fax: (865) 576-5728

Email: reports@adonis.osti.gov

This report is available to the general public from:

National Technical Information Service

U.S. Department of Commerce

5285 Port Royal Road

Springfield, VA 22161

Telephone: 1-800-553-6847 or

(703) 605-6000

Fax: (703) 321-8547

Internet: http://www.ntis.gov/ordering.htm 


\title{
Fusion Implementation
}

\author{
J.A. Schmidt
}

Princeton Plasma Physics Laboratory, P.O. Box 451, Princeton, New Jersey, 08543*

\begin{abstract}
If a fusion DEMO reactor can be brought into operation during the first half of this century, fusion power production can have a significant impact on carbon dioxide production during the latter half of the century. An assessment of fusion implementation scenarios shows that the resource demands and waste production associated with these scenarios are manageable factors. If fusion is implemented during the latter half of this century it will be one element of a portfolio of (hopefully) carbon dioxide limiting sources of electrical power. It is time to assess the regional implications of fusion power implementation. An important attribute of fusion power is the wide range of possible regions of the country, or countries in the world, where power plants can be located. Unlike most renewable energy options, fusion energy will function within a local distribution system and not require costly, and difficult, long distance transmission systems. For example, the East Coast of the United States is a prime candidate for fusion power deployment by virtue of its distance from renewable energy sources. As fossil fuels become less and less available as an energy option, the transmission of energy across bodies of water will become very expensive. On a global scale, fusion power will be particularly attractive for regions separated from sources of renewable energy by oceans.
\end{abstract}

\section{INTRODUCTION}

If the international fusion program meets its development goals then fusion will be part of a portfolio of energy sources during the last half of this century. It will likely be the case that this portfolio will be constrained by limits on carbon dioxide emissions. The mix of energy sources that make up this portfolio will depend in part on the systems aspects of the specific distribution system. These systems aspects will in turn depend on the uncontrolled availability of the power sources being used (e.g. wind). In addition regional factors such as the availability of primary energy resources (e.g. solar) will also play an important role. There will be regions that are more fertile for the introduction of fusion than other sources. Up until this point these factors have not been given serious consideration when developing fusion deployment scenarios. This report will illustrate some of the implications of deploying fusion reactors in a regional distribution system. We will focus on the Northeastern United States as an important region and on wind as one alternative. Wind power is chosen for illustrative purposes because it is relatively well developed and exhibits both temporal variations and regional resource limitations.

\footnotetext{
* Work performed under USDOE Contract \#DE-AC02-76CH03073
}

If fusion meets its development goals it will be a benign power source without regional limitations that would impede deployment within any distribution system. Provided that the cost of fusion power is competitive, the deployment of fusion reactors will depend to a significant extent on the regional "fertility" for other power sources.

\section{REGIONAL FACTORS}

As stated above we will focus on the Northeastern United States to illustrate regional factors and we will us wind power as a well developed alternative to fusion. The Northeast will be defined as the following states:

Connecticut

Delaware

Maryland

Massachusetts

New Jersey

Rhode Island

Maine

New Hampshire

Vermont

Virginia

New York

Pennsylvania

West Virginia

As a rough projection of electrical demand for this region we prorate the International Panel on Climate Control (IPCC) projections (IS 92a) according to present population [1]. This projection is shown in figure 1. To estimate the need for new non-emitting energy sources, we assume the limitations on emissions imposed by plateauing the atmospheric concentration of carbon dioxide at a level of $650 \mathrm{ppm}$. This curve is also shown in figure 1 . We see from these projections that roughly 0.1 Tera Watts of new non-emitting power sources will be needed by the end of this century. 


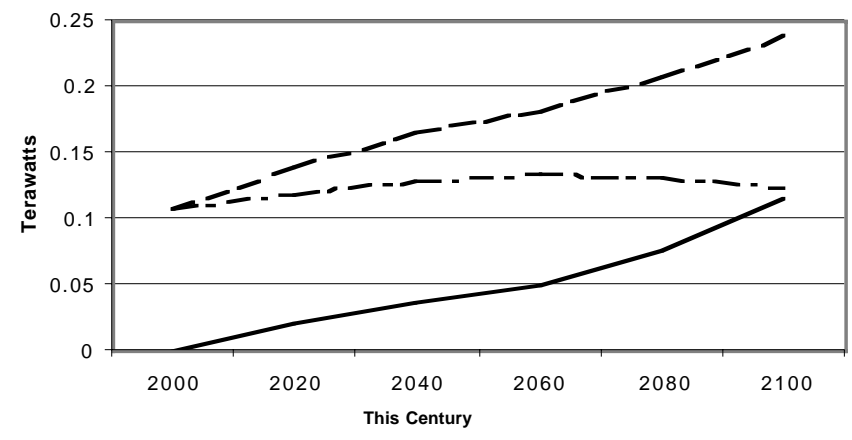

Fig. 1. Total electrical demand projections for the Northeastern United States along with the allowed power from fossil fueled plants if the atmospheric emissions are constrained to limit carbon dioxide in the atmosphere to $650 \mathrm{ppm}$. Also shown is the power from the associated noncarbon dioxide producing power plants.

As a basis for projecting wind power availability we use the resource estimates provided by Elliot, et al. [2]. Figure 2 shows plots of the wind power available as a function of distance from the coast measured directly east. The region considered is limited to states above the $37 \mathrm{~N}$ parallel. A moderate wind speed $(30 \mathrm{mph})$ is assumed along with two levels of environmental restriction on land use. These curves show the expected increase in wind power availability when approaching the Great Plains. 100,000 square kilometers translates to a little over 0.1 Tera Watts.

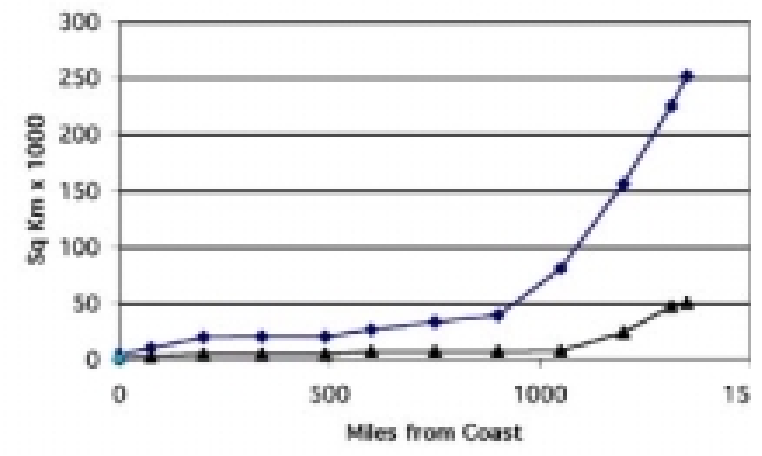

Fig. 2. Wind resources as a function of longitudinal distance from the Northeast coast for cases of low and significant environmental land exclusions.

If significant land use restrictions apply to wind power deployment, long distance transmission will be required between the Great Plains and the Northeast if wind is to be a significant source of power for this region. A likely scenario is for this power source to be used to supply regions closer to the Great Plains.

\section{IMPACT OF TEMPORALLY VARIABLE ENERGY SOURCES}

Again using wind as an example we will examine the consequence of temporally variable energy sources on a power distribution system performance. The primary value of a power unit in this system will be defined as its contribution to meeting peak demand. The contribution to periods of peak demand is the primary purpose for the capital investment in a power plant.

We assume an isolated power distribution system made up of 40 identical units with 0.9 uncontrolled availability. Increments of wind power will be added to this system from a source at one location, and the incremental increases in performance assessed. We will require that the system have a 0.9 probability of supporting each peak demand occurrence without a voltage reduction to reduce the demand. The power associated with a wind farm is the power averaged over a relevant season. We will assume a Rayleigh distribution [3] for the probability as a function of wind velocity. As a measure of value we will define a unit of credit as the fraction of a unit of the average power produced by the wind farm that can be used to replace a unit of high availability (e.g. 0.9 availability) central power (e.g. fusion or coal plant) while maintaining the probability of meeting peak demand at the 0.9 level.

Figure 3 shows a plot of the credit as a function of the fraction of the total distribution system that is represented by the wind unit. For low levels of wind application the variable system will get approximately full credit for the power installed. However, when the installed wind power level increases relative to the overall capacity of the distribution system, the value of the wind system measured against contributions to meeting peak demand drops rapidly.

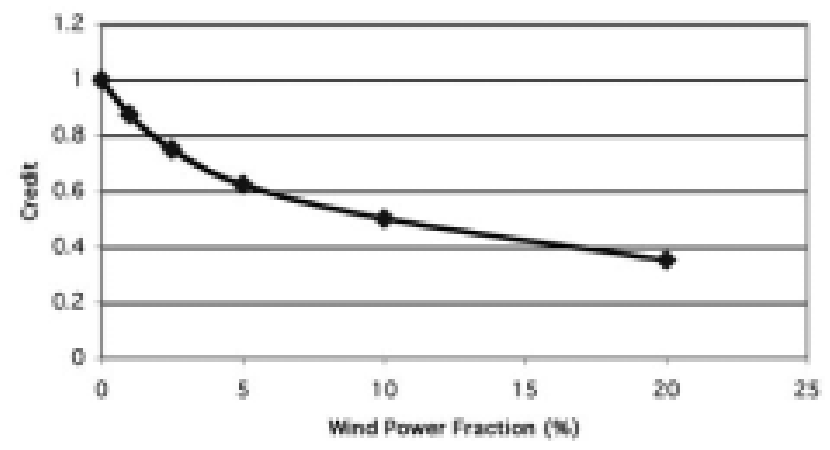

Fig. 3. The Credit that a wind power source at one location would receive relative to a 0.9 availability central power plant, is shown as a function of the fraction of the distribution system represented by the wind source.

\section{IMPACT OF ENERGY STORAGE}

It is commonly assumed that energy storage will alleviate the problem of variable power sources, if one is willing to pay for the construction and operation of the storage system. In most cases this is not true. To illustrate the systems aspects of energy storage consider Figure 4. We again recognize the fact that the important time to consider is during periods of peak demand. These periods occur during the day and usually in the summer. The storage system would be charged at night during a period of reduced demand. During this period, power is available to charge the storage system without depending on the wind power as long as the wind power is not too large a fraction of the total distribution system. If it is too large a fraction, problems could be encountered in meeting off peak demand. With the storage system charged for a period of peak demand, all available power sources will be callable including 
the storage and wind power. The wind power contribution will again be governed by figure 3 irrespective of the existence of the storage system.

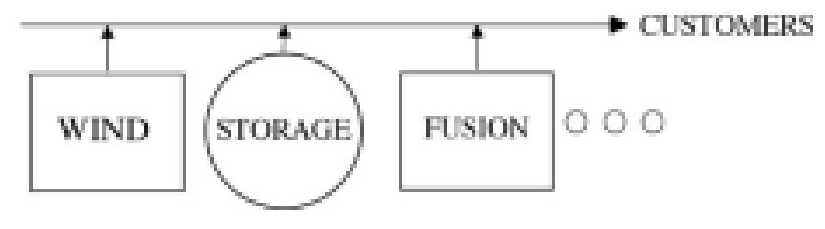

Fig 4. A conceptual power distribution system including energy storage.

\section{ACKNOWLEDGEMENT}

The author wishes to acknowledge Dr. Joan M. Ogden, of the Center For Energy and Environmental Studies, for discussions which contributed to this paper.

\section{REFERENCES}

[1] Climate Change 1994, Edited by J.T. Houghton, L.G. Meira Filho, J. Bruce, Hoesung Lee, B.A. Callander, E. Haites, N. Harris and K. Maskell (University Press, Cambridge, United Kingdom, 1995) pg 23.

[2] D.L. Elliott, L.L. Wendell, and G.L. Gower, An Assessment of the Available Windy Land Area and Wind Energy Potential in the Contiguous United States, Pacific Northwest National Laboratory, Richland, Washington, Report PNL-7789, UC-261 (August 1991) 61 pp

[3] Thomas B. Johansson, Henry Kelly, Amulya K.N. Reddy, and Robert H. Williams, Editors, and Laurie Burnham, Executive Editor, Renewable Energy: Sources for Fuels and Electricity, (Island Press, Washington, D.C., 1993) Chapter 3, Wind Energy: Technology and Economics, Cavallo, Alfred J., Hock, Susan M., and Smith, Don R. ; pp 121-156. 


\section{External Distribution}

Plasma Research Laboratory, Australian National University, Australia

Professor I.R. J ones, Flinders University, Australia

Professor J oão Canalle, Instituto de Fisica DEQ/IF - UERJ , Brazil

Mr. Gerson O. Ludwig, Instituto Nacional de Pesquisas, Brazil

Dr. P.H. Sakanaka, Instituto Fisica, Brazil

The Librarian, Culham Laboratory, England

Library, R61, Rutherford Appleton Laboratory, England

Mrs. S.A. Hutchinson, JET Library, England

Professor M.N. Bussac, Ecole Polytechnique, France

Librarian, Max-Planck-Institut für Plasmaphysik, Germany

J olan Moldvai, Reports Library, MTA KFKI-ATKI, Hungary

Dr. P. Kaw, Institute for Plasma Research, India

Ms. P.J . Pathak, Librarian, Insitute for Plasma Research, India

Ms. Clelia De Palo, Associazione EURATOM-ENEA, I taly

Dr. G. Grosso, Instituto di Fisica del Plasma, Italy

Librarian, Naka Fusion Research Establishment, J AERI, J apan

Library, Plasma Physics Laboratory, Kyoto University, J apan

Research Information Center, National Institute for Fusion Science, J apan

Dr. O. Mitarai, Kyushu Tokai University, J apan

Library, Academia Sinica, Institute of Plasma Physics, People's Republic of China

Shih-Tung Tsai, Institute of Physics, Chinese Academy of Sciences, People's Republic of China

Dr. S. Mirnov, TRINITI, Troitsk, Russian Federation, Russia

Dr. V.S. Strelkov, Kurchatov Institute, Russian Federation, Russia

Professor Peter Lukac, Katedra Fyziky Plazmy MFF UK, Mlynska dolina F-2, Komenskeho Univerzita, SK-842 15 Bratislava, Slovakia

Dr. G.S. Lee, Korea Basic Science Institute, South Korea

Mr. Dennis Bruggink, Fusion Library, University of Wisconsin, USA

Institute for Plasma Research, University of Maryland, USA

Librarian, Fusion Energy Division, Oak Ridge National Laboratory, USA

Librarian, Institute of Fusion Studies, University of Texas, USA

Librarian, Magnetic Fusion Program, Lawrence Livermore National Laboratory, USA

Library, General Atomics, USA

Plasma Physics Group, Fusion Energy Research Program, University of California at San Diego, USA

Plasma Physics Library, Columbia University, USA

Alkesh Punjabi, Center for Fusion Research and Training, Hampton University, USA

Dr. W.M. Stacey, Fusion Research Center, Georgia Institute of Technology, USA

Dr. J ohn Willis, U.S. Department of Energy, Office of Fusion Energy Sciences, USA

Mr. Paul H. Wright, Indianapolis, Indiana, USA 
The Princeton Plasma Physics Laboratory is operated by Princeton University under contract with the U.S. Department of Energy.

\author{
Information Services \\ Princeton Plasma Physics Laboratory \\ P.O. Box 451 \\ Princeton, NJ 08543
}

Phone: 609-243-2750

Fax: 609-243-2751

e-mail: pppl_info@pppl.gov

Internet Address: http://www.pppl.gov 